\title{
David Oliver: Is the ward round dead?
}

\author{
David Oliver consultant in geriatrics and acute general medicine
}

Berkshire

Has the ward round had its day? I recently enjoyed an animated conversation on Twitter with some junior doctors who had posed this question. ${ }^{1}$

My intuitive response? Absolutely not. Seeing and talking with each of our patients, reviewing their progress, treatment, and investigations, and planning their ongoing care or discharge, is what inpatient hospital doctors do. It's often accompanied by a multidisciplinary team discussion of all patients-perhaps a better use of non-medical staff time than traipsing after a medical entourage.

This all sounded like a ward round to me, so what was the problem? Besides, earlier in my career we consultants were often content to do the round twice a week, delegating most daily work to a team who worked more independently and unsupervised. Was that better for patients or for us?

Nowadays, frequent senior review is the norm, ${ }^{2}$ even at weekends. ${ }^{34}$ Consultants on acute assessment and intake are expected to see all newly admitted patients within hours rather than only on epic, morning-only, "post-take" ward rounds. We focus relentlessly on patient flow and discharge, sometimes at the expense of other priorities including teaching and training.

Senior doctors must sometimes provide the continuity, effectively presenting patients to juniors to get them up to speed

Were those modern juniors justified in their regret for a lost golden age? Maybe. Each week now brings a different permutation of junior doctors on the ward. They've often been doing shift work on take or doing out-of-hours ward cover and can't possibly know the patients. The senior doctors must sometimes provide the continuity, effectively presenting patients to the juniors to get them up to speed.

In the Royal College of Physicians' recent report Being a Junior Doctor ${ }^{5}$ trainees described the downsides of their working lives, including a lack of continuity; a gradual erosion of the traditional "firm" structure with its team ethos; a lack of opportunity for teaching, learning, and reflection; and less opportunity to take autonomous responsibility without "senior decision makers" diving in so early.

I reckon my friends on Twitter were mourning the chance to assess and initially manage patients, to present them to seniors, to learn and grow from the feedback, and to be patients' fulcrum of continuity.

But acute admissions are rising, as are patient turnover, frequency, and the pace of decisions. ${ }^{6}$ We have 3-4 hours to get around 25 or more patients - several new and unknown. Perhaps the biggest skills to learn are how to see all patients quickly and often, spot and stabilise the sickest, discharge the least unstable early, accept calibrated risk, cut corners, and prioritise. Peeling off mid-round to do pressing administrative jobs is inevitable. Delays deny beds to other patients.

If the ward round really is dead, then long live the ward round. Maybe it's simply had a reincarnation.

\section{Competing interests: See www.bmj.com/about-bmj/freelance-} contributors/david-oliver.

Provenance and peer review: Commissioned; not externally peer reviewed.

Follow David on Twitter, @mancunianmedic

1 Oates T, Simpson H, Oliver D, et al. "Is the ward round dead? I think it might be." Twitter. Dec 2016. https://twitter.com/toates_19/status/806194346005581824.

2 National Audit Office. Discharging older patients from hospital. 26 May 2016. https://www. nao.org.uk/report/discharging-older-patients-from-hospital/.

3 NHS England. Seven day services baseline data collection. https://t.co/OCafpg4acY

4 Royal College of Physicians. Statement on seven day services. 16 Jul 2015. https://www. rcplondon.ac.uk/news/rcp-statement-seven-day-services.

5 Royal College of Physicians. Being a junior doctor. 1 Dec 2016. https://www.rcplondon. ac.uk/guidelines-policy/being-junior-doctor.

6 Maguire D, Dunn P, McKenna H. King's Fund. How hospital activity and funding in England have changed over time. 20 Dec 2016. https://www.kingsfund.org.uk/publications/hospitalactivity-funding-changes.

Published by the BMJ Publishing Group Limited. For permission to use (where not already granted under a licence) please go to http://group.bmj.com/group/rights-licensing/ permissions 